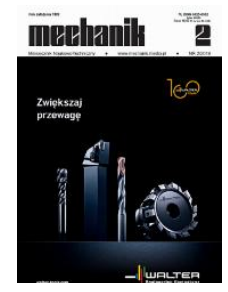

How to cite this article:

Authors: Łukasz Żurawski, Borys Storch

Title of article: „Durability identification of individual inserts used in the face milling cutter”

Mechanik, No. 2 (2019)

DOI: https://doi.org/10.17814/mechanik.2019.2.17

\title{
Durability identification of individual inserts used in the face milling cutter
}

\author{
ŁUKASZ ŻURAWSKI \\ BORYS STORCH *
}

\begin{abstract}
Dr inż. Łukasz Żurawski, lukasz.zurawski@tu.koszalin.pl, https://orcid.org/0000-0002-1158-1811 - Zespół Badawczo-Dydaktyczny Monitorowania Procesów Technologicznych, Katedra Inżynierii Systemów Technicznych i Informatycznych, Wydział Mechaniczny Politechniki Koszalińskiej, Koszalin, Polska

Prof. dr hab. inż. Borys Storch, borys.storch@tu.koszalin.pl, https://orcid.org/0000-0001-8576-5894 - Zespół Badawczo-Dydaktyczny Monitorowania Procesów Technologicznych, Katedra Inżynierii Systemów Technicznych i Informatycznych, Wydział Mechaniczny Politechniki Koszalińskiej, Koszalin, Polska
\end{abstract}

In this work, the milling process realizing by carbide inserts along with durability identification of each of individual inserts fixed in the cutting inserts-based multiple tool has been presented. The adopted hypothesis about a concurrent wear of the inserts, under conditions in which the relevant technological and physical factors were set, has been verified experimentally. The verification was based on analysis of workpiece surface roughness.

KEYWORDS: milling, wear, face milling cutter, insert

\section{Introduction}

On-line monitoring systems used in industry do not allow for identification of their wear. Hence the need to carry out the described tests, which are a step on the way to create direct systems for active control of the state of the tool during work on the machine tool. An indication of the wear condition of each cutting edge would make it easier to assess its suitability for further work $[1,2,6]$.

\section{Aim, scope and methodology of the research}

The paper sets out two main goals:

- examination of the wear of cutting edge, which will show whether the wear of the set of the exchangeable insert of the milling head has a determined course,

- assessment of the impact of the milling head working time on the determined roughness parameters.

A comparison of data from these two sources will confirm or exclude the importance of wear of cutting edges in the milling process.

Digital records of optically obtained images were used. They allowed for the determination of wear patterns on the application surface of individual cutting edges. After assembling the images of increasing wear according to the adopted methodology and comparing them with the visible scale of the pattern, the $V B b_{\text {smax }}$ abrasion values for the cutting edges on the superfinishing surface $A b_{s}$ were determined $[1,3]$. The measurements were repeated five times to obtain the average values, which were used to develop the graphs of the $V B b_{\text {smax }}$ wear tool relationship and the cutting path $L_{c}$. The cutting path was variable for three tested feedrates $v_{\mathrm{f}}$ in relation to the adopted limit of allowable wear of the cutting edge.

To present the results of wear courses for each of the eight inserts, the method of normalizing the determined values was used. The essence of standardization was that $100 \%$ was assigned the longest cutting length $L_{\mathrm{c}}$ and the largest wear tool $V B b_{\text {smax. }}$ Graphs obtained in this way illustrate the wear tool trends as a function of the path in the range of their changes $100 \%$ to $100 \%$.

Current wear tool values were compared for each of the eight corners with permissible criterion wear of the cutting edges $V B b_{\text {smax }}=0.4 \mathrm{~mm}$. The percentage increase in the wear tool determined in this way was plotted on the ordinate in the charts. Trends of normalized percentage shares are shown in figs. $3 b, 4 b$ and $5 b$. 
It has been assumed that normalization of results will simplify monitoring wear of the cutting edge process and surface roughness at every stage of tool operation in the milling head. For decades, a way of presenting the course of wear tool that would facilitate the decision to further cut or stop the process has been sought. It was assumed that wear tool processes occurring simultaneously on each cutting edge in a multiple tool, taking into account the axial run-out of the cutting edge under constant cutting conditions, are similar. It was expected that normalization of results would allow drawing important conclusions about the issue phenomena for cutting edges in multiple tools with several or many exchangeable inserts.

\section{Research stand}

Preliminary tests prompted the preparation of a test stand for monitoring wear of the cutting edge (fig. 1a$b$ ). The stand was equipped with a computer system and electronic metrological mechanisms with the possibility of digital image recording.

a)

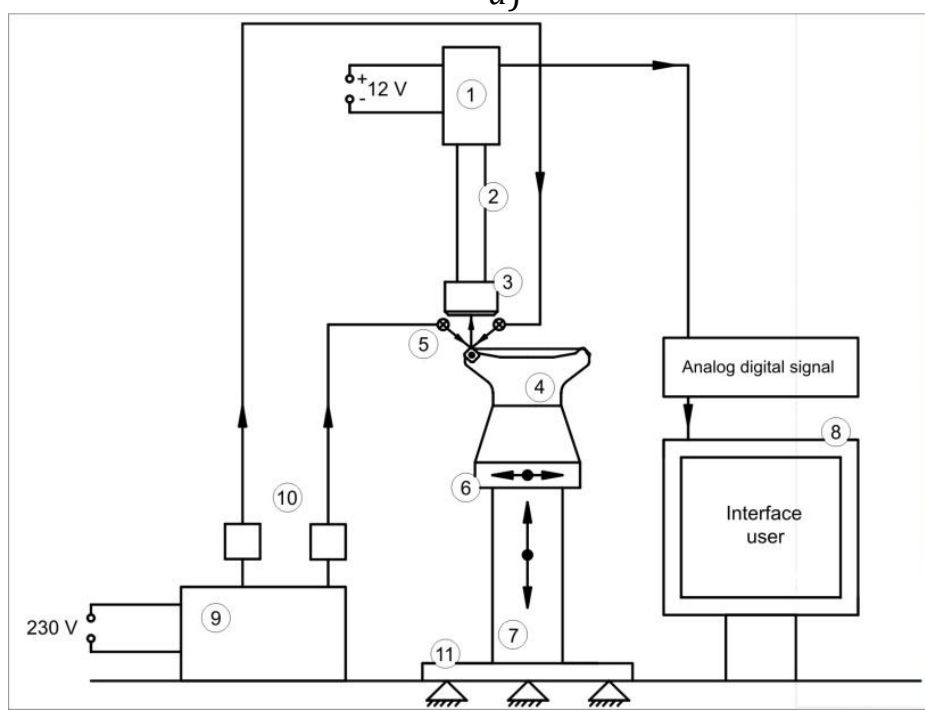

b)

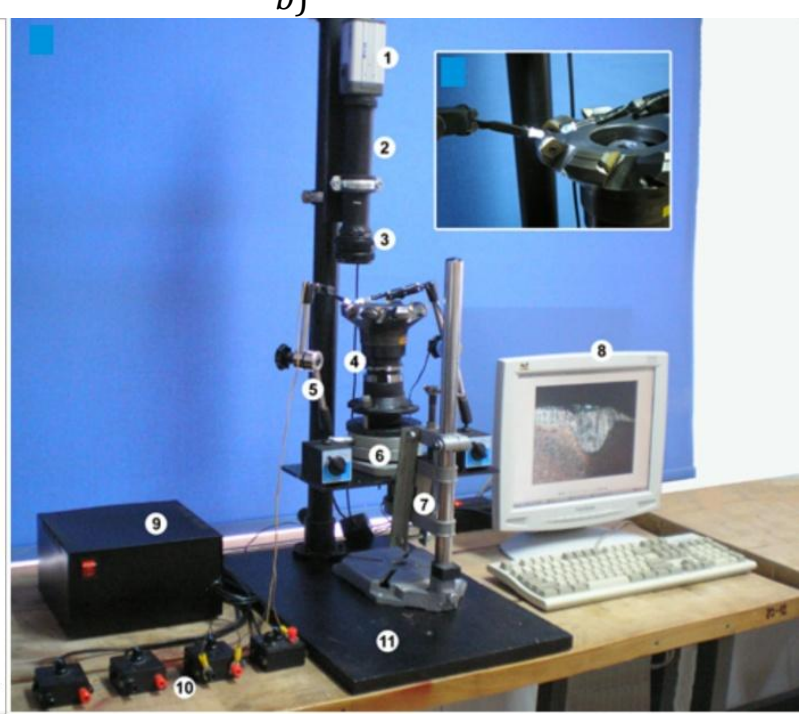

Fig. 1. Test stand for monitoring the tool wear: $a$ ) schematic diagram, $b$ ) general view

\section{Results}

The tests were carried out for commercially available exchangeable inserts R245-12 T3 M-PM 4230 with $b_{s}$ superfinishing edge (fig. $2 a$ ) and milling head R245-125Q40-12M (fig. 2b).

a)

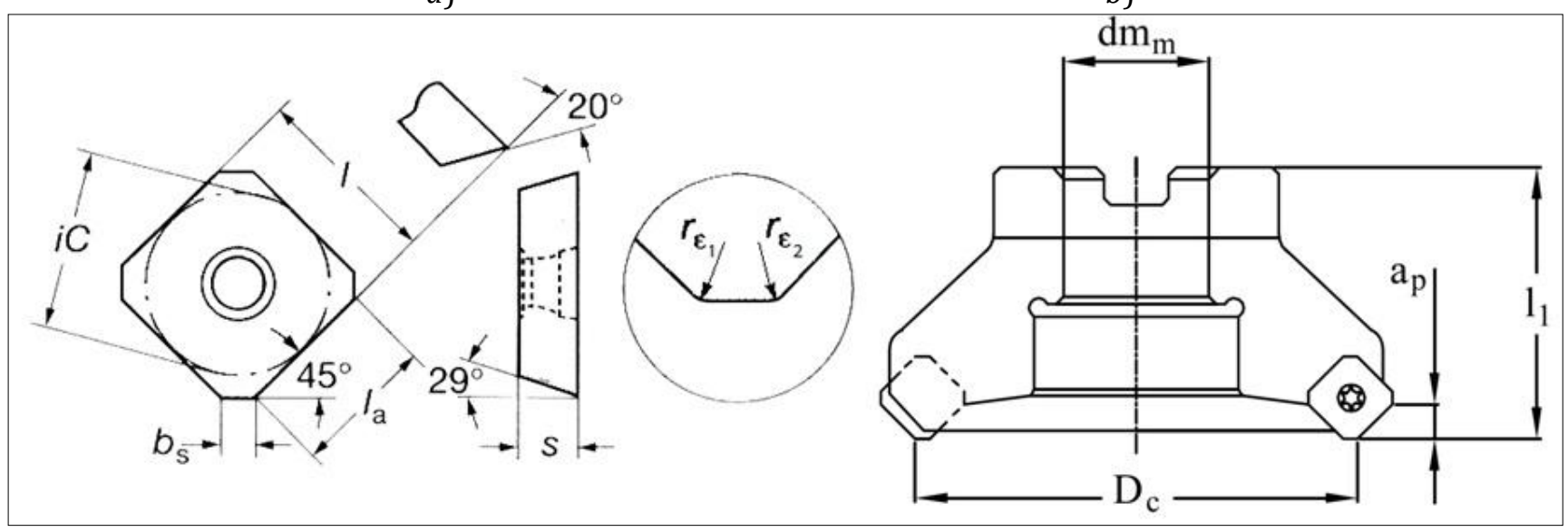

Fig. 2. Geometry of the exchangeable insert with superfinishing edge $b_{s}(a)$ and dimensions of the milling head $(b)$ [4] 
During milling on the FWD 32 machine tool of the EN C45 steel alloy, the following values of constant cutting parameters were adopted: cutting speed $v_{\mathrm{c}}=440 \mathrm{~m} / \mathrm{min}$, cutting depth $a_{\mathrm{p}}=1 \mathrm{~mm}$, cutting width $a_{\mathrm{e}}=100 \mathrm{~mm}$. Variable feedrate $v_{\mathrm{f}}$ was a variable parameter.

At the feedrate $v_{\mathrm{f}}=355 \mathrm{~mm} / \mathrm{min}$, measurements wear of the cutting edge were carried out after five consecutive sections of the cutting length $L_{c}$ through the insert, which traveled a total of $1813 \mathrm{~m}$. The measurement points were determined in accordance with the test plan published in [1].

Based on the measurements, it was observed that the initial wear values of $V B b_{\text {smax }}$ were in the range of $0.05 \div 0.1 \mathrm{~mm}$. After approximately $600 \mathrm{~m}$ of milling, wear of the cutting edge values of the $V B b_{\text {smax }}$ began to be divergent and until the end of the cutting length $L_{c}$, they behaved characteristic for each of them. The inserts visibly worn differently.

a)

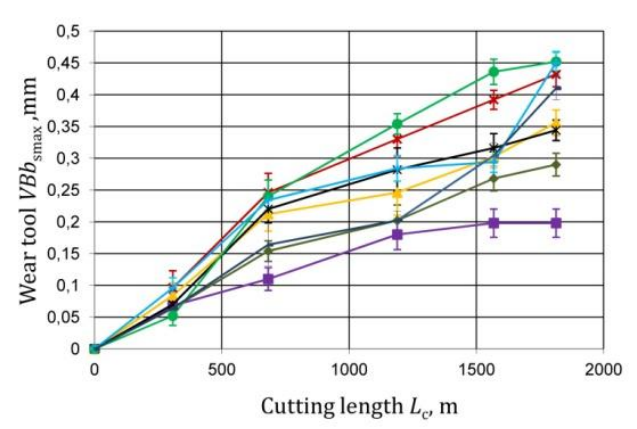

b)

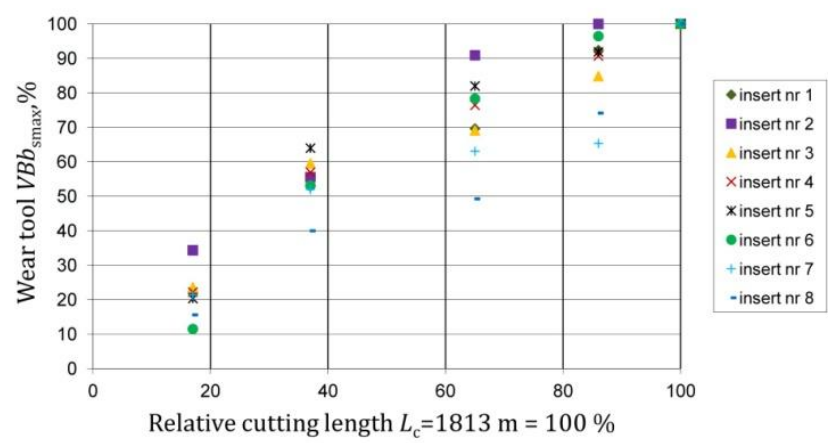

Fig. 3. Impact of the cutting length $L_{c}$ on: $a$ ) wear curves of the superfinishing surfaces $A b_{s}$ of exchangeable inserts and $b$ ) their percentage share for milling with feedrate $v_{\mathrm{f}}=355 \mathrm{~mm} / \mathrm{min}$

a)

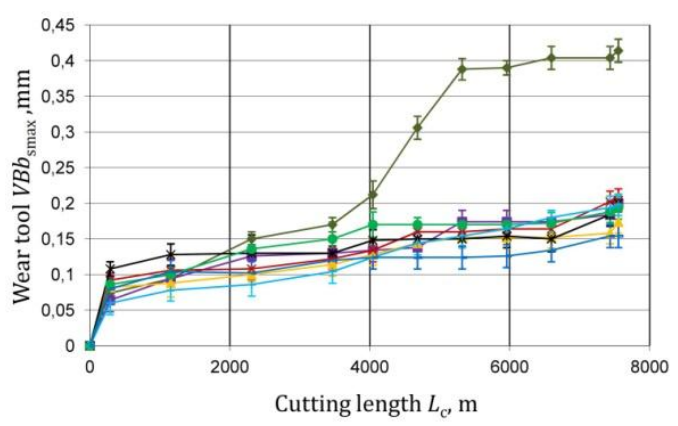

b)

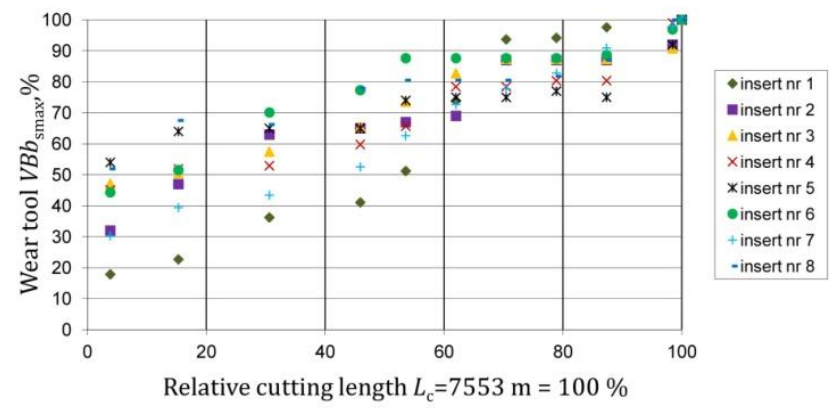

Fig. 4. Impact of the cutting length $L_{\mathrm{c}}$ on: $a$ ) wear curves of the superfinishing surfaces $A b_{\mathrm{s}}$ of exchangeable inserts and $b$ ) their percentage share for milling with feedrate $v_{\mathrm{f}}=710 \mathrm{~mm} / \mathrm{min}$

a)

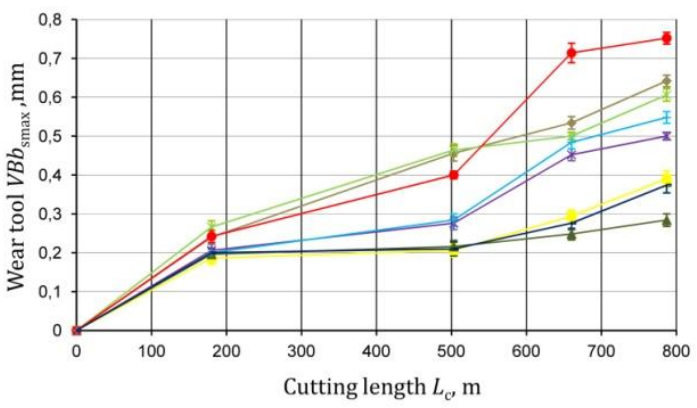

b)

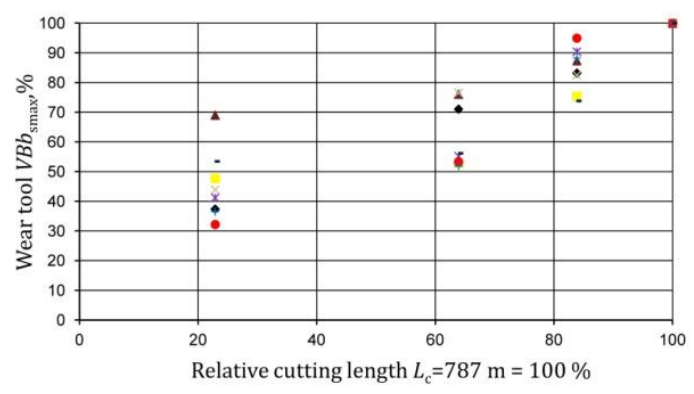

- insert nr 1 insertnr 2 $\Delta$ insert nr 3 $X$ insert $n r$
$\times$ insert nr 5 -insert nr 6 +insert nr 7 -insert nr 8

Fig. 5. Impact of the cutting length $L_{\mathrm{c}}$ on: $a$ ) wear curves of the superfinishing surfaces $A b_{\mathrm{s}}$ of exchangeable inserts and $b$ ) their percentage for milling with feedrate $v_{\mathrm{f}}=1120 \mathrm{~mm} / \mathrm{min}$ 
The highest wear occurred on inserts No. 4-6, medium - on inserts No. 3, 7, 8 and the smallest - on inserts No. 1 and 2 (fig. $3 a$ ). This course explains the relationship between wear of the cutting edge and its frontal beating, described in [1]. The smallest wear was observed on insert No. $2\left(V B b_{\text {smax }} \cong 0.2 \mathrm{~mm}\right)$, and the largest on insert No. $6\left(V B b_{\text {smax }} \cong 0.45 \mathrm{~mm}\right)$.

Results of increasing wear of the cutting edge for the next tested feedrate $v_{\mathrm{f}}=710 \mathrm{~mm} / \mathrm{min}$ are shown in fig. $4 a$. Measurements were made for eleven points on a cutting length $L_{\mathrm{c}}$ of $7553 \mathrm{~m}$.

At the beginning of the cutting length $L_{c}$, wear of the cutting edge of the $V B b_{\text {smax }}$ ranged from $\sim 0.06$ to $\sim 0.11$ $\mathrm{mm}$. After $2300 \mathrm{~m}$ of milling, the wear value of insert No. 1 began to increase and after $5300 \mathrm{~m}$ of cutting distance $V B b_{\text {smax }} \cong 0.39 \mathrm{~mm}$. The wear value of this insert increased linearly to the end of milling. The wear values of the other inserts slightly changed to finally reach $V B b_{\text {smax }}$ from $\sim 0.15$ to $\sim 0.2 \mathrm{~mm}$.

For the next feedrate $v_{\mathrm{f}}=1120 \mathrm{~mm} / \mathrm{min}$, wear of the cutting edge was measured after four increasing cutting length $L_{\mathrm{c}}$ sections, which was $787 \mathrm{~m}$ (fig. $5 a$ ).

After $180 \mathrm{~m}$ of milling, the wear of the cutting edge values of the $V B b_{\text {smax }}$ ranged from $\sim 0.19$ to $\sim 0.26 \mathrm{~mm}$. Further cutting caused the wear to increase in different ways depending on the cutting edge. The increase in wear value of insert No. 6 after $500 \mathrm{~m}$ milling was clear. After testing, the wear range of $V B b_{\text {smax }}$ for all inserts ranged from $\sim 0.4$ to $\sim 0.75 \mathrm{~mm}$.

At this feedrate, the relationship between the front run-out and wear tool was not clearly correlated. Insert No. 5 was the most extended and should be used as soon as possible. Meanwhile, its wear tool was in average values, and the most worn inserts were No. 1 and 4, which belonged to the least protruding from the tool body.

\section{Machined surface roughness tests}

Interactions occur between the cutting edge - and more specifically its auxiliary attachment surface - and the machined surface. Traces wear of the cutting edge create unevenness on the machined surface [5].

a)

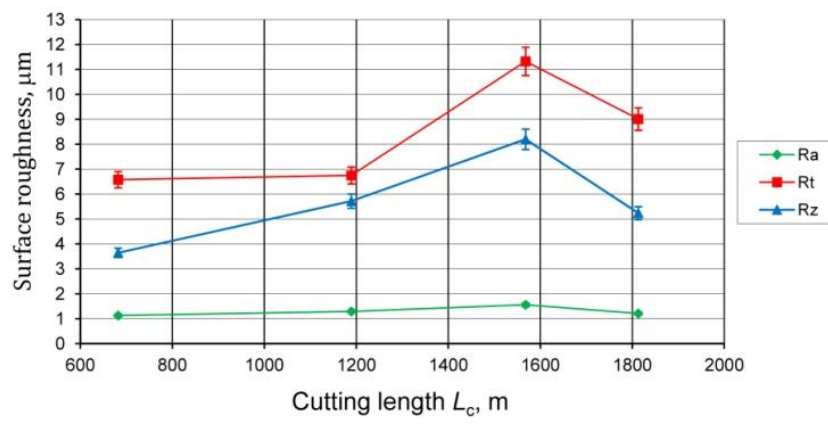

b)

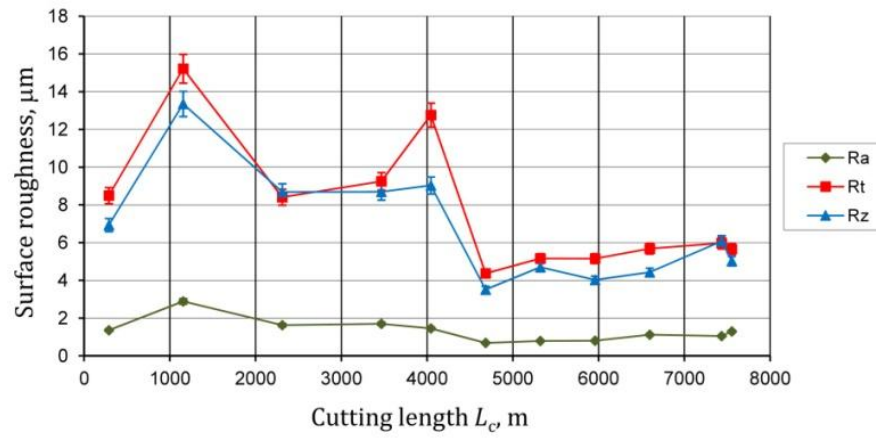

c)

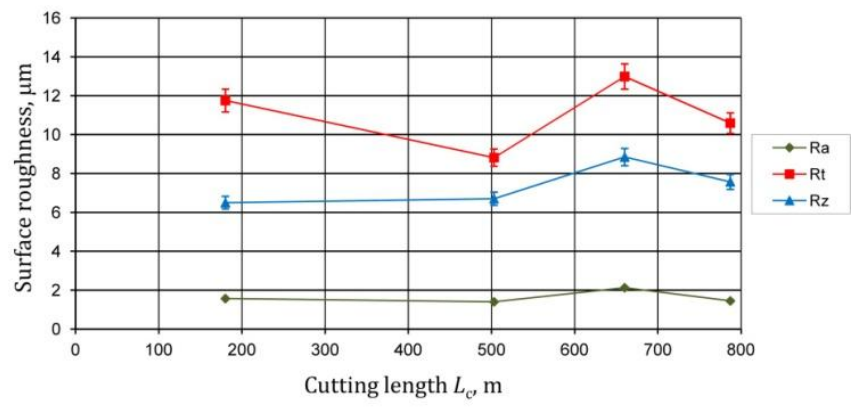

Fig. 6. The course of changes in the surface roughness parameters machined during milling at the feedrate: a) $\left.\left.v_{\mathrm{f}}=355 \mathrm{~mm} / \mathrm{min}, b\right) v_{\mathrm{f}}=710 \mathrm{~mm} / \mathrm{min}, c\right) v_{\mathrm{f}}=1120 \mathrm{~mm} / \mathrm{min}$

In multiple tool, with inserts equipped with an superfinishing surface $A b_{s}$, the effect of its wear marks on the final surface structure depends on the surface structure of one of the exchangeable inserts. After some time, the resulting unevenness is influenced by several inserts with identical or similar frontal run-out values. If exchangeable inserts with superfinishing surface $A b_{\mathrm{s}}$ are used, it can be seen that the surface irregularities 
depend on the part of the wear cutting edge that is in the vicinity of the second corner rounding radius $r_{\varepsilon 2}$ and is shifted by the feedrate value in the direction of corner $r_{\varepsilon 1}$ [1].

In assessing the surface unevenness test results, statistical methods were used to describe the roughness using the $R a, R z$ and $R t$ parameters. Measurements were made after the assumed cutting path intervals $L_{\mathrm{s}}$. The results were used to develop plots of surface roughness as a function of cutting length $L_{c}$ for three feedrates of milling table $v_{\mathrm{f}}$.

Roughness measurements carried out after milling at a feedrate $v_{\mathrm{f}}=355 \mathrm{~mm} / \mathrm{min}$ (fig. $6 a$ ) show that after 700 m cutting length $L_{c}$, roughness parameters increased: $R a$ from 1 to $1.3 \mu \mathrm{m}, R z$ from 3.5 to $5.5 \mu \mathrm{m}, R t$ from 7.5 to $7.8 \mu \mathrm{m}$. After $1800 \mathrm{~m}$, the parameter values decreased to $R a=1.1 \mu \mathrm{m}, R z=5.2 \mu \mathrm{m}, R t=9 \mu \mathrm{m}$.

Roughness measurements carried out after milling at a feedrate $v_{\mathrm{f}}=710 \mathrm{~mm} / \mathrm{min}$ (fig. $6 b$ ) show that after $200 \mathrm{~m}$ cutting length $L_{c}$, the roughness parameters increased to the following values: $R a$ from 1.3 to $3 \mu \mathrm{m}, R z$ from 7 to $13 \mu \mathrm{m}, R t$ from 8.5 to $15.4 \mu \mathrm{m}$. After $1200 \mathrm{~m}$, the parameter values decreased: $R a$ to $2.8 \mu \mathrm{m}, R z$ to 8.5 $\mu \mathrm{m}, R t$ to $8.5 \mu \mathrm{m}$. The measurement after $3400 \mathrm{~m}$ of cutting length $L_{\mathrm{c}}$ showed that the values of $R t$ and $R z$ parameters increased again and the $R a$ parameter decreased. After $4700 \mathrm{~m}$, all parameters decreased by almost half their value and reached: $R a=0.6 \mu \mathrm{m}, R z=3.8 \mu \mathrm{m}, R t=4.1 \mu \mathrm{m}$. Measurements of roughness parameters on subsequent sections of the cutting length $L_{c}$ showed that their values increased slightly and reached for: $R a=1.3 \mu \mathrm{m}, R z=5 \mu \mathrm{m}, R t=5.7 \mu \mathrm{m}$.

After measuring the roughness of the machined surface with a feedrate $v_{\mathrm{f}}=1120 \mathrm{~mm} / \mathrm{min}$ (fig. $6 c$ ), it was found that after $180 \mathrm{~m}$ the cutting length $L_{\mathrm{c}}, R a$ and $R t$ decreased from 1.8 to $1.7 \mu \mathrm{m}$ and from 11.8 to $8.9 \mu \mathrm{m}$, respectively, while the $R z$ parameter increased from $6.5 \mu \mathrm{m}$ to $6.8 \mu \mathrm{m}$. After reaching $500 \mathrm{~m}$ cutting, the values of all parameters increased: $R a$ to $2.1 \mu \mathrm{m}, R z$ to $8.8 \mu \mathrm{m}, R t$ to $13 \mu \mathrm{m}$. After traveling $650 \mathrm{~m}$, the values decreased, and after further cutting, the measured parameters reached the values: $R a=1.7 \mu \mathrm{m}, R z=7.7 \mu \mathrm{m}$, $R t=10.6 \mu \mathrm{m}$.

\section{Summary}

The main purpose of the research was to verify the hypothesis that in precisely determined cutting conditions of the milling head (cutting speed clearly set, cutting inserts from one production series, machined material with fixed mechanical properties, machine tool with fixed dynamic characteristics), in which interference, mechanism runs were eliminated, wear of the cutting edge should be similar within the measurement error limits.

In [2], the method of determining wear of the cutting edge histories in the $100 \% \times 100 \%$ system was thoroughly analyzed, in which the longest waveforms are compared to the largest wear of the cutting edge. During the tests, changes in surface roughness parameters were observed at the same time, which deteriorated or remained unchanged after reaching wear of the cutting edge limit values of the cutting edge and were poorly observed for individual insert workflows. Due to clearly different courses, it cannot be unequivocally acknowledged that, despite the most important cutting conditions established, there is a similarity of the concurrent wear mechanism of eight inserts in the milling head, which would allow using this indicator to monitor the milling process.

\section{REFERENCES}

[1] Żurawski Ł. „Analiza topografii powierzchni kształtowanych z użyciem wieloostrzowych narzędzi frezerskich z ostrzami o zróżnicowanym ukształtowaniu". Rozprawa doktorska. Koszalin: 2013.

[2] Zawora J. „Charakterystyka zużycia ostrza w funkcji pracy”. Podstawy technologiczne wielokryterialnej optymalizacji procesów toczenia złożonych powierzchni narzędziami punktowymi. Warszawa: Oficyna Wydawnicza Politechniki Warszawskiej, 2013.

[3] Żurawski Ł. Storch B. „Wizyjne stanowisko optyczne do obserwacji zużycia ostrzy w głowicy frezowej”. Mechanik. 8-9 (2013): 169-173.

[4] „Narzędzia skrawające - Katalog główny”. Sandvik, Szwecja, 2009.

[5] Storch B. „Wzajemne oddziaływanie naroża ostrza i materiału skrawanego”. Wrocław: Wydawnictwo Politechniki Wrocławskiej, 1989.

[6] Żurawski Ł., Chodór J., Kułakowska A. „Wpływ parametrów skrawania w procesie frezowania walcowoczołowego dla największej wydajności obróbki i trwałości ekonomicznej”. Technika Transportu Szynowego. 12 (2015): 2215-2219, bwmeta1.element.baztech-9b92d778-c0bb-443f-81f3-342433afb61d. 